\title{
NOTES OF THE QUARTER.
}

(October, November, December, 1893.)

\section{Orituary Notices.}

Prof. S. M. Georgiecsky.-We deeply regret to announce the early death of Prof. S. M. Georgievsky, Professor of Chinese in the Faculty of Oriental languages at St. Petersburg, who died this summer at Metz. After studying at the St. Petersburg University, where he took the degree of B.A., he went to China, and lived there for four years in different places. Then he returned to Russia and took the degrees of master and doctor of Chinese, and was finally appointed to the position of the Professor of Chinese. The following is a complete list of his works:-

1. Pervii period kitaiskoi istorii. (First period of Chinese history [to the Emperor Ch'ing-shi-u'wan-ti]). St. Petersburg, 1888.

2. O kornevom sostave kilaiskago jazika $\mathrm{v}$ svjai s voprosom o proishojdenii kitai chev. (The analysis of the radical sounds of the Chinese language in connection with the question of the origin of the Chinese people.) Large 8vo. pp. 127. St. Petersburg, 1888.

3. Analys hierogliphicheskoi pismennosti kitaichev, kak otrajainshei na sebe istoriu jizni drevniago kitaiskago naroda. (The analysis of the Chinese hieroglyphical letters as reflecting the history of the ancient Chinese people.) 8vo. St. Petersburg, 1888.

4. Princhipi jizni Kitaia. (The principles of the life of China.) pp. 492. St. Petersburg, 1888. 
5. Vajnost izychenia Kitaia. (The importance of the study of China.) 8vo. pp. 286. St. Petersburg, 1890.

6. Drevneishia moneti kitaichev. (The ancient Chinese coins.) 1889.

7. Graf. J. Tolstoi i "Princhipi jizni Kitaia." (Count J. Tolstoi and "The principles of the life of China.")

8. Miphologicheskia vozzenia kitaichev. (The mythological beliefs of the Chinese.) St. Petersburg, 1892.

D. $\mathbf{P}$.

Prof. Georg von der Gabelentz.-We regret to announce the death of Prof. Georg von der Gabelentz, which lately occurred at Berlin, at the comparatively early age of fiftythree. Born at Posehwitz, near Altenburg, he early took to the study of Eastern languages under the direction of his father, Prof. Hans Conon von der Gabelentz, who, in the first half of the century, was well known for his works on the Orient, and more especially for his knowledge of the Manchu language and literature. After having studied at the Universities of Jena and Leipzig, the subject of the present notice was appointed Professor of the languages of Fastern Asia at Leipzig in 1878. Two years before this date he had published a translation of the Chinese philosophical work entitled Thai khi thu by Chow Tun e. Later he published, among other works, a treatise on "Confucius and his Teaching," but, beyond question, his magnum opus was his Chinese Grammar, which is in every way worthy of his reputation. Those scholars who attended the meetings of the Oriental Congress in Germany and elsewhere, and who remember the stalwart form and bearing of Prof. der Gabelentz, will share in the surprise and regret so generally felt at the early close of his scholarly career.

Major-General Sir Alexander Cunningham.-By the death of General Sir Alexander Cunningham, K.C.I.E., C.S I., C.I.E., R.E., on 28th November last, another link with the past is severed, for he had been a member of our Asiatic Society for full thirty-eight years. Born in John Street, 
Westminster, January 23rd, 1814-little more than three years after his father, Allan Cunningham, came from Dalswinton, near Dumfries, in the hope of bettering his circumstances-he was only 14 years of age and his eldest brother, John Davey, 16, in May 1828, when Sir Walter Scott, breakfasting one morning with their father, "looked round the table, and said: "What are you going to make of all these boys, Allan?' 'I ask that question often at my own heart,' said Allan, 'and I cannot answer it.' 'What does the eldest point to?' 'The callant would fain be a soldier, Sir Walter, and I have half a promise of a commission in the king's army for him; but I wish rather that he could go to India, for there the pay is a maintenance, and one does not need interest at every step to get on.' "Scott went to Lord Melville (then President of the Board of Control), who gave him a promise of a cadetship for one son. Five days later (May 23rd), dining with Lady Stafford, he met the two brothers Loch, and Mr. John Loch also gave him a like promise. "Next morning," says Lockhart, "Sir Walter appeared at Sir F. Chantrey's breakfast-table, and greeted the sculptor" (in whose employ Allan Cunningham was) with-' I suppose it has sometimes happened to you to catch one trout (which was all you thought of) with the $\mathrm{fly}$, and another with the bobber. I have done so, and I think I shall land them both. Don't you think Cunningham would like very well to have cadetships for two of those fine lads?' 'To be sure he would,' said Chantrey, 'and if you'll secure the commissions, I'll make the outfit easy." "This was the way friends helped each other in those days, and thus the great Antiquary moulded the career of the later investigator. The late $\mathrm{Mr}$. Edward Thomas, too, used to tell with glee, how he received his 'accolade' or succession as an antiquary from the same hands: for when a boy, fishing in the Tweed, Sir Walter used to pat him on the shoulder and call him 'his young Antiquary.'

Allan Cunningham's fourth son, Francis Cunningham (born 1820), also went to India, entering the Madras Army 
in 1838 , but retired from ill-health as Lieut.-Colonel in 1862. He afterwards devoted himself to literature-editing Massinger, Marlowe, and Ben Jonson; and at the time of his death, in 1875 , he was engaged on a new edition of his brother Peter's well-known " Handbook of London."

With his next younger brother, Peter, Alexander Cunningham was educated at Christ's Hospital. After passing through the Military College, at Addiscombe, he went out to India and obtained his first commission as second-lieutenant in the Bengal Engineers in June, 1831. As early as 1834 he was appointed one of the aides-de-camp to GovernorGeneral, Lord William Bentinck, and was afterwards sent on a special mission to Kashmir in 1839. Being in his earlier years resident in Calcutta, he soon came into relations with James Prinsep. "During a great part of the years 1836 and 1837, the most active period of his career," wrote Cunningham in 1871, "I was in almost daily intercourse with Prinsep. With our mutual tastes and pursuits this soon ripened into the most intimate friendship. I thus had the privilege of sharing in all his discoveries during their progress." And, he adds, "when I recollect that I was then only a young lad of twenty-three years of age, I feel as much wonder as pride that James Prinsep should have thought me worthy of being made the confidant of all his great discoveries." Prinsep was then working on the newly discovered Baktrian and Saurashtran or Ksbatrapa coins, and on the Aśoka and Sânchi inscriptions, and we readily trace these same subjects all through Cunningham's subsequent career and in most of his writings. It is Prinsep's work continued through this early communication of his contagious enthusiasm.

The only paper Cunningham wrote during this period was contributed to the Journal of the Bengal Asiatic Society for Dec. 1834, and is titled (1) "Correction of a mistake regarding one of the Roman coins found in the Tope at Manikyala, opened by M. Court" (vol. iii. pp. 635-37). James Prinsep left India, a dying man, in Outober, 1838. The same year Lassen's aualysis of the legends on Bactrian 
coins was published, and in March, 1840, the first instalment of Dr. Roer's translation of it appeared in the Bengal Society's Joumal, and this work was strongly stimulative of research in India.

In 1840 Lieutenant Cunningham was employed as engineer to the King of Oudh, and began to be a frequent contributor to the Journal. His papers in 1840 were(2) "Notice of some Counterfeit Bactrian coins" (vol. ix. pp. 393-96) ; (3) "Notes on Captain Hay's Bactrian coins" ( b. pp. 867-89), a "Note" to the same paper (ib. p. 1008); and (6) "Second notice of some forged coins of the Bactrians and Indo-Scythians" (ib. pp. 1217-30). In the following year appeared-(7) "Abstract Journal of his route in 1839 to the sources of the Panjab rivers" (vol. x. pp. 105-15); (8) "Description of some Ancient Gems and seals from Bactria, the Panjab, and India" (ib. pp. 147-157); and (y) "A Sketch of the Second Silver Plate found at Badakshân" (ib. pp. 570-72). To the February number for 1842 of the same Journal, he sent (10) his "Second notice of some new Bactrian Coins" (vol. xi. pp. 130-137), at the end of which he announced that he was then engaged on a large work on the "Coins of Alexander's Successors in the East"-a work that was long delayed, though it finally appeared in the Numismatic Chronicle.

After this, for six years, he contributed only one more paper to the Bengal Journal. But he was by no means idle: in September, 1842, in a letter to Col. Sykes, published in our Journal (Vol. VII. pp. 241-47), he gave(11) "An Account of the Discovery of the Ruins of the Buddhist city of Samkassa"; and to the Numismatic Chronicle-(12) "The Ancient Coinage of Kashmir, with chronological and historical notes" (vol. vi. pp. 1-38); and (13) "An attempt to explain some of the Monograms on the Grecian Coins of Ariana and India" (vol. viii. pp. 175-97). In the 1843-44 he served in the Gwalior campaign, with the force under Major-General Grey, and was present at the battle of Paniâr, 29th December, 1843; and in February, 1844 , he was appointed executive officer on the staff of the 
Gwalior contingent. Here he again returned to his old studies and published in the Bengal Journal-(14) "Notice of some unpublished Coins of the Indo-Scythians" (vol. xiv. pp. 430-41).

In 1846 he was sent on a mission through Kulu and Lahul into Ladâk; and of this trip to the Chu-Murari Lake, he published (15) the "Journal" in 1848 (J.A.S. Beng. vol. xvii. pt. i. pp. 201-330), and (16) a "Memorandum detailing the boundary between the territories of Mahârâjâ Gulâb Singh and British India as determined by the Commissioners, P. A. Vans Agnew, Esq., and Capt. Cunningham" (ib. pp. 295-297). From Jan. 1847 to 1849 he was engaged as engineer for laying down the boundaries of the Northwest frontier, and during the latter part of this period he served in the Panjab campaign of 1848-49, including the battles of Chilianwâlâ, 13th Jan. 1849, and Gujarât, 22nd Feb., when he received the brevet rank of major.

In 1848 we find him starting a new subject, to which he constantly recurred in succeeding years. MM. Remusat, Klaproth, and Landresse had translated the Foe-koue-ki, or Travels of $\mathrm{Fa}$ Hian, into French, appending to their version the itinerary of Hiuen Thsang; and J. W. Laidlay had, that year, rendered it into English with additional notes, but omitting the itinerary. Major $\mathrm{Wm}$. Anderson impugned the authenticity of Hiuen Thsang's work, urging that it was a modern compilation, and Capt. Cunningham replied in his paper: (17) "Verification of the Itinerary of Hiuen Thsang through Ariana and India, with reference to Major Anderson's hypothesis of its modern compilation." (J.A.S. Beng. vol. xvii. pt. i. pp. 476-88). This he followed up by (18) a second paper on the same subject (vol. xvii. pt. ii. pp. 13-60).

In June, 1848, he sent to the Calcutta Society (19) a letter on a "Proposed Archæological Investigation" to be conducted at Government cost by an officer "conversant with the sculptured forms and religious practices of the present day, and with the discoveries made by Prinsep and others in Indian Palæography and Numismatology" 
(vol. xvii. pt. i. p. 535). This was the first germ of what he was afterwards personally to carry out.

His next paper, (20) "An Essay on the Arian Order of Architecture, as exhibited in the Temples of Kashmir" (vol. xvii. pt. ii. pp. 241-327, with 18 plates), was a more ambitious attempt in a new direction, and was, perhaps, the least successful of his works. His acumen in numismatics and topography did not serve him in architectural archæology ; but the drawings were most valuable and instructive.

In 1850 he was employed as Executive Engineer of the Gwalior State, and at the same time Capt. F. C. Maisey was making drawings for the Court of Directors of the remarkable sculptures of the Sânchi gateways. Meeting with Maisey in October of that year he arranged to visit Sânchi, while on tour, and open the Topes,- - his brother, Capt. J. L. Cunningham, being then Resident at Bhopal. Accordingly, he arrived on 23rd January, 1851, and next morning began sinking a shaft in the centre of the great Stûpa, in which he found some relic caskets. Of his work here and at the stupas in the neighbourhood he gave a short account in a paper contributed to our Journal-(21) "Opening of the Topes or Buddhist Monuments of Central India" (Vol. XIII. 1851), pp. 108-114. In December, 1852, he had been made Executive Engineer at Multân, and while in this office he produced his first properly separate work, (22) “The Bhilsa Topes; or Buddhist Monuments of Central India: comprising a brief historical sketch of the Rise, Progress, and Decline of Buddhism; with an account of the opening and examination of the various groups of Topes around Bhilsa" (1854, 8vo. pp. 368), with 33 plates. Nearly half this volume is devoted to a sketch of Buddhist history, and about a fourth of it to the donative inscriptions, chiefly on the rails and pillars, of which he copied about 200 from the great stîpa, and 43 from the smaller. More have been found since. Some of these had already been treated of by Prinsep, but Cunningham made translations of the whole, which-considering the state of Prâkrit scholarship forty years ago-were very creditable to his scholarship. 
This was followed by his volume (23) " Ladâk: Physical, Statistical, and Historical" (London, 1854). Within a year he contributed to the Journal of the Bengal Society (vol. xxiii. pp. 679-714) a paper-(24) on "Coins of Indian Buddhist Satraps, with Greek Inscriptions," at the close of which he lays claim to the discovery of eleven letters of the Ariano-Pali alphabet before the publication, eight years previously, of Mr. Norris's alphabet in 1846.

$\mathrm{He}$ was then, in October 1856, sent to Burma, as Chief engineer in Pegu and Tenasserim, and his next paper in 1860, was an official one-(25) "Memorandum on the Irâwadi River, with a monthly register of its rise and fall from $1856^{\circ}$ to 1858 , and a measurement of its maximum discharge" (J.A.S. Beng. vol. xxix. pp. 175 ff.). Again, in September 1858, he was transferred as Chief Engineer to the NorthWestern Provinces and a Secretary to the Government.

In 1860 Lord Canning agreed to institute an Archæological Survey, at least of Upper India, and General Cunningham, who had previously proposed this, drew up a memorandum on the plan of operations. Towards the end of 1861 he was appointed to superintend this survey, and began operations in December of that year. (26) His first year's report (for 1861-62) was published in 1863 as a supplementary number of the Bengal Asiatic Society's Journal (vol. xxxii.), and to the same he contributed both a paper and note-(27) " Remarks on the Bactro-Pali Inscription from Taxila" (vol. xxxii. pp. $139 \mathrm{f}$. and $172 \mathrm{f}$., vol. xxxiii. pp. 35-38); (28) "Remarks on the date of the Pehewa Inscription of Râja Bhoja" (vol. xxxiii. pp. 223-32); (29) a note on the results of a tour in the Panjab ( $i b$. pp. 332-33); and another-(30) on the identification of the

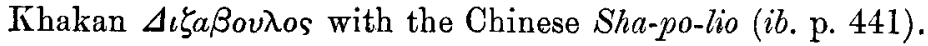
His (31) "Report of the Proceedings of the Archæological Surveyor to the Government of India for the season 1862-63" was published partly as a supplementary number (No. lxxxvii.) to the volume for 1864, and concluded in vol. xxxiv. pp. 155-278. His other papers in 1865 were(32) “On the Antiquities of Bairat," etc. (Proc. 1865, 
p. 97), and (33) "Coins of the Nine Nâgas, and of two other dynasties of Narwar and Gwalior" (vol. xxxiv. pt. i, pp. 115-12厅).

In June, 1862, General Cunningham had retired from the army with the rank of Major-General. In the cold season of 1863-64 he made a tour in the Panjab, and in 1864-65 he explored the region between the Jamnâ and Narmadâ. The reports of these investigations were printed subsequently as Government papers, and at a later date (in 1871) the whole four Reports were reprinted in two volumes octavo with additional plates. But in 1866 Lord Lawrence abolished the appointment of Archæological Surveyor, and for a season these useful and important labours were stopped, and General Cunningham returned to England.

In 1867 we find him busy writing in the Numismatic Chronicle-(34) on a "Coin of the Indian prince Sophytes, a contemporary of Alexander the Great"; and, in 1868-73, -(35) "Coins of Alexander's Successors in the East, the Greeks and Indo-Scythians "-an important series of papers (n.s. vol. viii. pp. 93-136, 181-213, and 257-83; vol. ix.

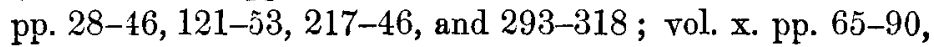
205-36; vol. xii. pp. 157-85, and vol, xiii. pp. 187-219). In March, 1869, he contributed to Dr. Forbes Watson's "Report on the Illustration of the Archaic Architecture of India," etc. (36) a "Memorandum on the Archæological Remains of India" (pp. 25-34). His (37) "Ancient Geography of India, vol. i. The Buddhist Period" (8vo.pp. 589) was published by Trübner in the end of 1870. In this he gathered together the information he had already published respecting the route of the Chinese pilgrims, and extended the survey to the whole of India, as had already been done by M. Vivien de Saint-Martin in his Mémoire published in 1858 ; but Cunningham worked out in more detail the geography of the Panjab in elucidation of the campaign of Alexander.

Dr. Forbes Watson's paper with its enclosures from Mr. James Fergusson and others, brought up afresh the question of a survey; but, as stated by Mr. Markham, "it was 
necessary that the researches should be conducted in a more systematic manner, and on some definite plan; and in July, 1870, it was resolved that a central establishment should be formed to collect the results of former researches, to train a school of archæologists capable of conducting local enquiries, and to direct, assist, and systematize the various efforts and enquiries made by local bodies and private persons, as well as by the Government. The direction of this establishment was offered to General Cunningham," and he left England to resume "those interesting labours which had already occupied so many years of his life, in December, 18r0." $\mathrm{He}$ had then almost completed his fifty-seventh year - an age when most men are obliged to leave active service in India. The appointment was only for five years, but he continued to hold it for fifteen.

Before leaving England, he wrote for this Journal-(38) a "Note" on Professor Dowson's paper on the Mathura Inscriptions (Vol. V. pp. 193-96), and, on reaching India, his first work was to reprint his old reports, to the first volume of which he prefixed an introduction of 43 pages, giving an outline of previous research, with most interesting reminiscences of his personal intercourse with James Prinsep.

In his new position he formed no central establishment to collect results, and was not very fortunate in his assistants; but he toured much himself, and sent them out to survey different places and districts in India north of the Narmadâ, and in the Central Provinces; Western India being left to the independent survey of Dr. Burgess. (39) The Reports of his own and his assistants' work were issued from time to time during the fifteen years of his office, in twenty-one thin volumes, the consultation of which has been greatly facilitated by the preparation of an excellent Index volume by Mr. Vincent A. Smith, of the Civil Service, which enables the student, as far as it is practicable, to get over the difficulty presented by the want of any systematic arrangement, or even references to previous volumes in which the same place has been referred to. In addition to these reports, he issued, in 1877, the first volume of 
(40) his "Corpus Inscriptionum Indicarum" (demy 4 to. pp. 142), with thirty plates representing the Inscriptions of Aśoka. These plates, apparently drawn very neatly with his own hand, produced the inscriptions of Aśoka, as then known, taken from eye copies. The second volume was to have contained the Indo-Scythian and other early inscriptions, and for this most of the plates were printed off some time before he retired, but the volume has not yet appeared ; the third volume, devoted to the Gupta inscriptions, was prepared by Dr. J. F. Fleet, and issued in 1888.

General Cunningham printed also a special volume in 1879, (41) "The Stûpa of Bharbut" (4to. pp. 143), with fifty-seven plates-one of his best works; and, in 1883, (42) "Book of Indian Eras with Tables for calculating Indian Dates" (8vo. pp. 22 $\tilde{)}$ ), based on Captain Warren's standard work, but which has not met with any wide acceptance. Besides several short notices of coins, etc., in the Proceedings of the Bengal Asiatic Society, he contributed to its Journal, in 1881 and 1883, a paper (43) on "Relics from Ancient Persia, in Gold, Silver, and Copper" (vol. l. pt. i. pp. 151-86; vol. lii. pt. i. pp. 64-67 and 258-60).

Like all his father's family, he was a big man, and a fall which he had from an elephant at fully seventy years of age injured him very severely. After this, on the completion of fifteen years in the survey, he retired in 1885, in his seventy-second year, with an augmented pension. In May, 1871, he was made C.S.I. ; in January, 1878, C.I.E.; and, after retirement, in February, 1887, K.C.I.E.

During his stay in India, having availed himself of his special opportunities, he had formed a very large and valuable collection of sculptures, coins, and other objects of antiquarian interest. With the exception of the more valuable coins, he shipped these, together with books, papers, note-books, photographic negatives, etc., for England, and, most unfortunately, the vessel一the P. and $O$. steamer 'Indus' - in which they were, was wrecked on the Mullaittivu coral reef on the N.E. cosst of Ceylon, and the collection perished: the loss to science we shall never know. 
After his return to England he was by no means idle. To the Numismatic Chronicle (1889) he contributed (44) " Coins of the Tochari, Kushâns, or Yue-ti" (3rd. s. vol. ix. pp. 268-311); and in 1890 and 1892 (45) "Coins of the Sakas (vol. x. pp. 103-72; vol. xii. pp. $40-82$ and 98-159). In 1891 he reproduced a number of his numismatical papers in a volume on "Coins of Ancient India," in which he detailed his opinions respecting the origin of money, and described numerous Indian coins of obscure origin. Next year he wrote (46) an "Introductory Note" for the volume on 'Sânchi and its Remains' by his old associate General Maisey, and also brought out a handsome volume (47) on "Mahâbodhi, or the Great Buddhist Temple under the Bodhi Tree at Buddha-Gaya" (sup. roy. 4to. pp. 87) with 31 plates. In this work he gives a detailed account of the results of the excavations made at the temple under his supervision twelve years previously. Its late appearance may be partly accounted for by the loss of the photographic negatives along with his collections; for the collotypes in this volume have been made from photographic prints, which had fortunately been preserved. Then, to the London meeting of the International Congress of Orientalists in Sept. 1892, he sent a paper (48) on the "Ephthalites, or White Huns" (Trans. vol. i. pp. 222-244), a subject which M. Vivien de St.-Martin also had long before treated in a valuable paper.

Though he was afflicted by a painful malady, which latterly confined him to bed, he still preserved a keen interest in his favourite study, and even during his last year he sent three fresh papers to the Numismatic Chronicie :(49) "Later Indo-Scythians" (3rd s. vol. xiii. pp. 93-128), with two continuations of the same, viz. (50) "Scytho-Sassanians" (ib. pp. 166-183), and (5l) “Little Kushâns" (ib. pp. 184-202). These were his last public contributions to our knowledge of Oriental coins, but almost to the last he took pleasure in talking about and examining his favourite treasures, and even answering correspondents.

Sir Alexander Cunningham was the natural successor to 
Colonel Colin Mackenzie and James Prinsep, also self-made antiquaries: he did not possess the scholarship and judicial mind of a Colebrooke, or the faculties of comparison and scientific deduction of a Fergusson or a Rickman. He belonged to the older school; but his indefatigable devotion to his subject, and to the acquisition of all information that might be helpful to him, was scarcely less than marvellous. Hence, perbaps, his great success in numismatics and in identifying old sites, whilst into the wider and higher fields of comparative archæology and architecture he seemed little inclined to advance, and where he did, his active imagination led him into theories often unscientific and without solid bases. In philology and chronology, too, he was prone to frame bypotheses without sufficient justification-suggested by imagination or misinterpretation. And even in the identification of sites he occasionally accepted, from his assistants, positions on grounds so insufficient as to excite our surprise. In the translation of inscriptions-like other early pioneers-he depended for guidance on native pandits, rather than on European scholars best able to help him, and but seldom consulted those whose willing aid be could readily bave commanded. This detracted from the permanent value of much of his work. But, with all necessary deductions, the value of that work is acknowledged to be great in itself, and for the impetus it has given to research in the same and in connected branches of Oriental archæology.

Personally, he was most gentlemanly, courteous, affable, and full of interesting information, which he delighted to pour forth. His literary power was hereditary, and his style was descriptive and literary rather than strictly scientific: he wrote out of his own knowledge, and was sparing of references to authors who had already treated the same question, or for the fuller elucidation of his topic. But even in his antiquarian work he sometimes let his imagination have play, and burst into verse of good quality and finish-as witness the conclusion to his Bhilsa Topes. 